UDC 621.646: 532.546

O. Koroliov ${ }^{1}$, DSc, Prof., P. Pavlyshyn ${ }^{2}$

${ }^{1}$ Odessa National Polytechnic University, 1 Shevchenko Ave., 65044 Odessa, Ukraine; e-mail: korolov@opu.ua

${ }^{2}$ Rivnenska AES, Varash, Rivne region Ukraine, 34400; e mail: office@rnpp.atom.gov.ua

\title{
DEVELOPMENT AND RESEARCH OF THROTTLE-REGULATING VALVES WITH INCREASED EROSION RESISTANCE
}

О.В. Корольов, П.Я. Павлишин. Розробка і дослідження дросельно-регулюючого вентиля 3 підвищеною ерозійної стійкістю. Надійність і безаварійність роботи атомних станцій обумовлена надійністю роботи трубопровідних систем, що пов'язують основне і допоміжне обладнання. Основними елементами таких систем є енергетична арматура (клапани, вентилі та ін.), надійна робота якої багато в чому визначає надійність АЕС в цілому. При цьому однією $з$ проблем, що знижують ресурс арматури, $\epsilon$ ерозійний знос основних їі елементів. Стаття присвячена розробці і експериментальному дослідженню вентиля 3 підвищеною стійкістю до ерозійного зносу. В статті показані проблеми, які пов'язані з експлуатацією вентиля і, як наслідок, обумовлюється актуальність дослідження. Слід зазначити, що дослідження вентиля запропонованої конструкції виконується вперше. Особливістю конструкції вентиля є те, що робоче середовище, проходячи орган регулювання, потрапляє в пористу засипку, де відбувається ефективне гасіння швидкості потоку і пов'язаного з цим шумом. Представлена експериментальна конструкція вентиля і описаний експериментальний стенд для його дослідження, дається опис методів дослідження. Для дослідження течії в пористому шарі вентиля використовувалися 12 датчиків, заведених всередину шару. У якості пористої засипки використовувався дрібний поліетилен, тому експеримент проводився на низькому тиску і при нормальних температурах. В результаті експерименту отримано розподіл тиску в пористому шарі в залежності від ступеня відкриття вентиля і збільшення витрати через нього. Отримано нелінійні залежності на середніх витратах і лінійні на максимальних і мінімальних витратах. Встановлено, що в такому вентилі ділянка 3 високою швидкістю середовища буде перебувати в пористої засипці. Дослідження гідравлічної характеристики показало, що вона має характер близький до лінійного, подібний для течій в пористих середовищах.

Ключові слова: ерозія, вентиль нової конструкції, експеримент, розподіл тиску, видаткова характеристика

O. Koroliov, P. Pavlyshyn. Development and research of throttle-regulating valves with increased erosion resistance. The reliability and trouble-free operation of nuclear power plants is due to the reliability of the pipeline systems connecting the main and auxiliary equipment. The main elements of such systems are power valves, the reliable operation of which largely determines the reliability of the NPP as a whole. At the same time, one of the problems that reduce the service life of the reinforcement is the erosive wear of its main elements. The article is devoted to the development and experimental research of reinforcement with increased resistance to erosion wear. The problems associated with the operation of valves and the relevance of the raised problem are shown. It should be noted that the study of such a valve is performed for the first time. A feature of the valve design is that the medium, passing through the regulator, does not leave the valve, but enters the porous filling, where the flow rate and associated noise are effectively damped. The article presents an experimental design of such a valve and describes an experimental stand for its research, gives a description of research methods. To study the flow in the porous layer, 12 sensors were used, inserted into the layer. Fractional polyethylene was used as a porous backfill, therefore the experiment was carried out at low pressures and normal temperatures. As a result of the experiment, the pressure distribution in the porous layer was obtained depending on the degree of valve opening and the increase in flow through it. Nonlinear dependences are obtained at average flow rates and linear at maximum and minimum flow rates. It has been established that in such reinforcement the section with a high velocity of the medium will be in a porous backfill. The study of the hydraulic characteristic showed that this characteristic has near linear character, similar for flows in porous media.

Keywords: erosion, valve of new design, experiment, pressure distribution, flow characteristic

\section{Introduction}

The successful implementation of technological processes at nuclear and thermal power plants requires strict control and compliance with the operating parameters of the main and auxiliary equipment.

An important role in this process is assigned to pipeline systems and, in particular, shut-off and control valves. The device of modern valves allows to work in a wide range of pressures and temperatures, to operate at significant pressure drops, to realize the hydraulic characteristics $[1,2,3]$ required for technological purposes. However, the main problem of such valves is erosive wear of the regulating bodies associated with the high speed of water flowing through it $[4,5,6]$.

\section{DOI: 10.15276/opu.3.62.2020.08}

(C) 2020 The Authors. This is an open access article under the CC BY license (http://creativecommons.org/licenses/by/4.0/). 
Analysis of the literature and the formulation of the problem of the research topic

Despite a wide selection of valve designs, the operational stations and designers are faced with the problem of creating valves for large pressure drops, with low noise characteristics and high erosion resistance.

Recently, a lot of attention has been paid to the development of valves and the reasons for this are:

a) the lack of universal recommendations for the design of valves when working in a pipeline system in variable modes;

b) the absence of valve structures that reliably operate at large pressure drops.

In the latter case, the reliability of work is determined by a whole set of conditions that ensure the normal functioning of the system. These are erosion resistance, reduction of the noise and vibration level of the system, as well as the stability of the hydraulic characteristics of the valve. The state of the problem now is such that repair work on valve elements is constantly increasing its share in the total volume of work on auxiliary equipment. Almost at all energy enterprises there are malfunctions in the operation of the main equipment associated with erosion damage to pipes and fittings, which lead to unscheduled shutdowns of units and an increased expenditure of funds for repair work. Damage to valves due to wear accounts for about $27 \%$ of the total number of damage to valves [4]. The analysis of accidents at power plants shows that $12.5 \%$ of cases are accounted for by accidents associated with erosional destruction of equipment $[5,6]$.

Now the problem of eliminating erosion damage to power fittings remains open. This is due, among other things, to the lack of a reliable theory of erosional destruction in closed systems, such as pipelines and fittings themselves [7].

The purpose and objectives of the study

The aim of the article is the development and experimental study of the valve, as a reinforcement element with improved erosion resistance.

To achieve this goal, the following tasks are formulated:

1. Based on the analysis of the literature, determine the main trends in the development of erosion-resistant reinforcement.

2. Develop the concept and basic design of the valve.

3. Carry out an experimental study of the proposed design.

Analysis of reinforcement structures aimed at reducing erosive wear

1. Solutions aimed at increasing the survivability and stability of the valve are divided into passive and active. In the first case, these are methods of protecting the metal of the body and the executive body from the erosion effects of the flow. In the second case it is an improvement in the operating conditions of the valve by acting on the hydrodynamics of the working medium with additional devices. If the installation of jackets made of high-strength stainless steel (usually O8XI8H9T) can be considered useful as a temporary measure, then from a long-term perspective, such solutions are uneconomical and the possibility of their destruction during long-term operation is not excluded. Cladding of the inner surface of the reinforcement in conditions of mass production is an expensive and not always effective operation, since it leaves the possibility of thermal fatigue destruction of the metal at variable operating modes of reinforcement [8]. The introduction of surfactants into the cycle, allowing reducing the erosive effect of the flow on the reinforcement, is often not always possible due to technological conditions [9]. Structures with profiled executive bodies are becoming widespread, however universal methods have not been found for the arrangement of the flow-through part of the valve, which makes it possible to work at large pressure drops with high stability of the hydraulic characteristics and good erosion resistance. The developments of recent years allow tracing the development trends of throttling and control valves in order to establish a promising direction for the development of valve structures.

2. The first type according to the functional attribute should include valves with reduced hydraulic losses in the executive body. As, for example, devices with an actuator such as a needle valve, the calculation method of which is quite well developed [7]. 
However, given that the main part of the pressure in the valve is lost due to irreversible losses during the conversion of kinetic current energy into pressure energy, single-stage actuators are strong sources of noise and erosion, since the damping of the flow energy occurs in the pipeline sections that are located behind the valve and are not intended for these purposes, which leads to a significant reduction in the resource of their work.

Thus, at Lukomolskaya Power Plant, a solution [10] was proposed, aimed at reducing the erosion of pipelines behind the choke, however, this led to the displacement of the area of maximum destruction to the executive body. The next step in the modernization of the valves was the development of multi-stage throttling devices $[3,7]$, which make it possible to reduce the flow rate in each of the stages and, at the same time, implement a mode with increased erosion resistance. However, in this case, the occurrence of cavitation in the actuator was observed and additional adjustment of the fittings to the corresponding parameters of the technological process was required. To damp the kinetic energy of the jet within the volume of the actuator, a well-proven scheme of the cellular actuator is used. The scheme still has a drawback, namely, the presence of high flow rates at low degrees of opening of the actuator. The most suitable for work with large pressure drops are structures that implement multi-stage throttling using the principle of mutual jet damping. Such designs have proven themselves well as noise-reducing devices that operate reliably at pressure drops up to $14 \mathrm{MPa}$.

\section{Development of a valve resistant to erosion wear}

The above designs show the current trend in the development of multistage throttle devices, which consists in increasing the pressure response stages and using the principle of mutual extinguishing of jets directly in the actuator. In our opinion, one of the solutions to this problem will be the implementation of the throttling process in porous media, where the ideal pressure response process is realized without significant pressure drops. A device of this type can be a valve with an actuator made of an artificial porous medium with a given law of porosity distribution, both along the height and along the radius of the reinforcement. A device of this type requires careful theo-

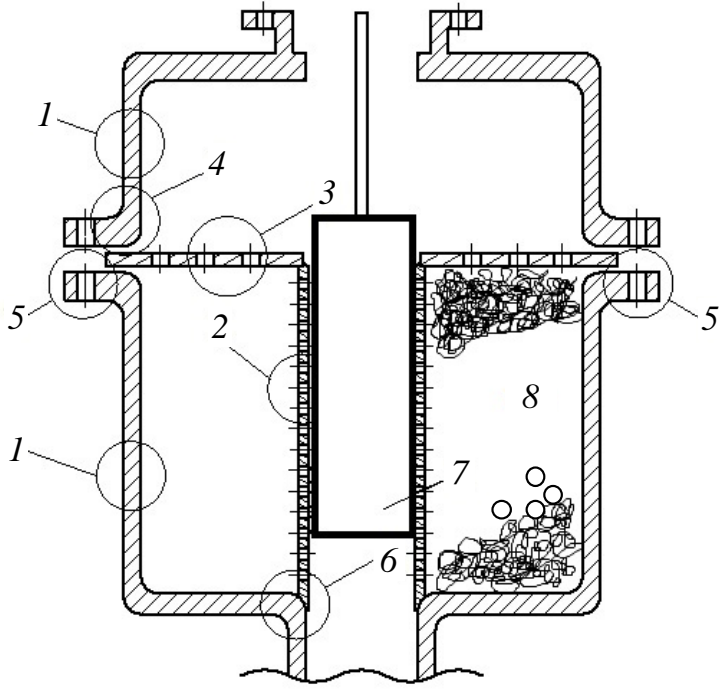

Fig. 1. The basic design of the valve with porous filling: 1 - body; 2 - inner perforated tube; 3 - perforated diaphragm; 4 - body-flange connection; 5 - flange with holes for studs; 6 - place of installation of a perforated tube in the valve body; 7 - regulating body (piston with rod), 8 - filling zone of the porous body retical analysis and experimental verification in order to establish the hydraulic characteristics and the subsequent issuance of recommendations for their practical application at the station. A valve with a porous backfill was subjected to experimental research (see Fig. 1). Valve body 1, all internal elements were made of stainless steel 08X18H10T. Between body 1, diaphragm 3 and inner perforated tube 2 , there was a filling of polyethylene cylinders $3 \ldots 4 \mathrm{~mm}$ in diameter and $5 \ldots 6 \mathrm{~mm}$ in length. The piston 6 had a height of the working part equal to the height of the perforated tube 2 for correct operation of the valve.

\section{Description of the stand for the experimental study of the valve}

The study of the design of valves with distributed actuation of pressure in the porous layer was carried out on the installation, the diagram of which is shown in Fig. 2. The installation consists of a tank with water 1 with a volume of $0.75 \mathrm{~m}^{3}$, to which a centrifugal pump 3 with a flow rate of $70 \mathrm{~m}^{3} / \mathrm{h}$ and a pressure of $0.34 \mathrm{MPa}$ was connected.

The pump has a bypass line 4 for finer flow control. The flow rate was measured with an integrating tube 5 installed in a pipeline with an inner diame- 
ter of $50 \mathrm{~mm}$. To study the pressure distribution in the porous layer along the body, 12 impulse lines were installed, connected to tubes of $1.6 \mathrm{~mm}$, brought into the center of the porous filling.

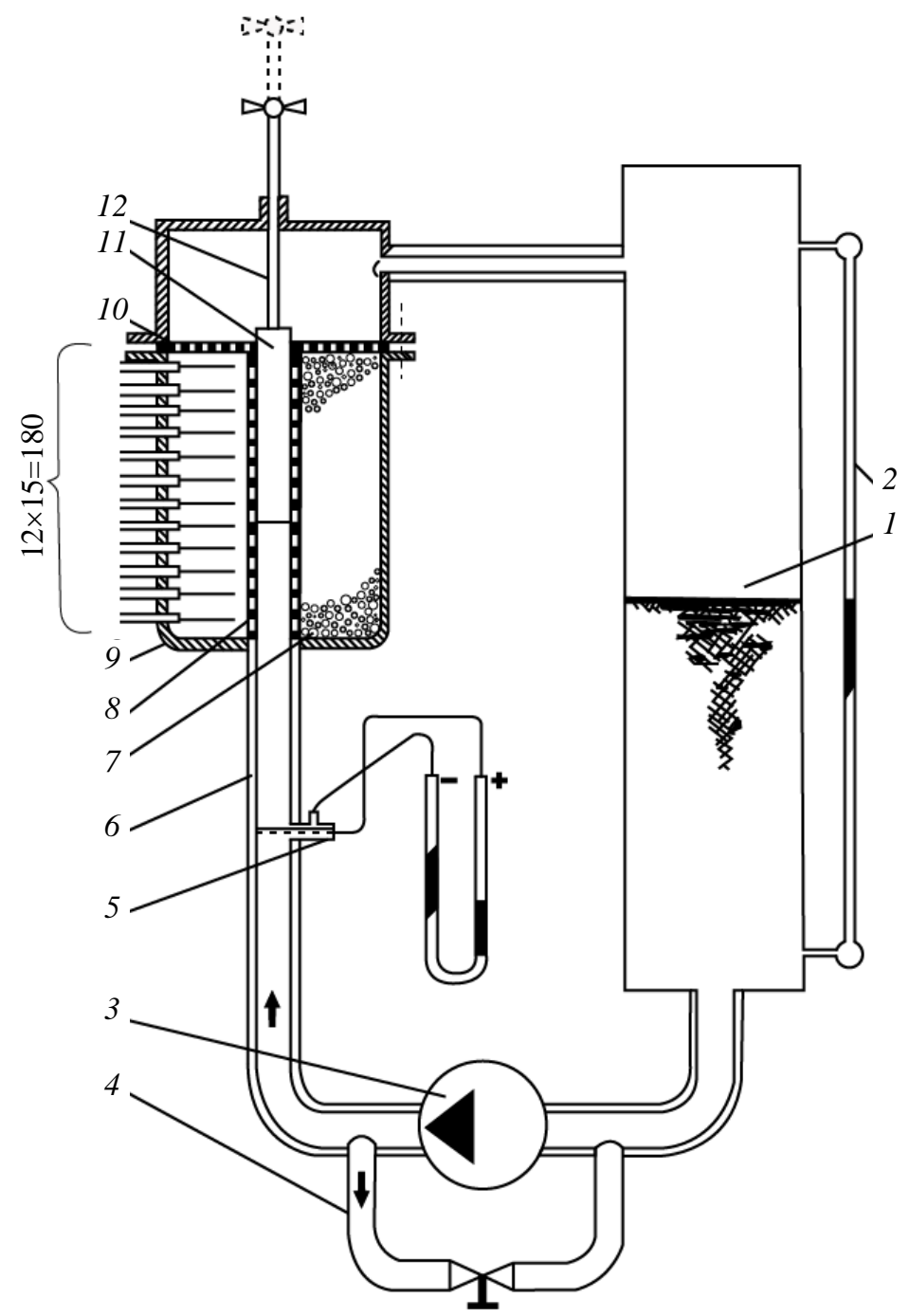

Fig. 2. Schematic diagram of the installation for examining valves with porous filling: 1 - tank with water supply; 2 - level gauge; 3 - centrifugal pump; 4 - bypass line; 5 - flow tube; 6 - supply pipeline; 7 - porous filler; 8 - central perforated tube; 9 - case; 10 - perforated diaphragm; 11 - piston; 12 - stock

\section{Research results and their analysis}

The main task of the study was to study the pressure distribution in the porous backfill. Figure 3 shows the dependence of the static pressure on the height of the porous material (12 rows by $180 \mathrm{~mm}$ ).

It can be seen from the graphs that a nonlinear distribution of pressure at average flow rates is observed in the free backfill. At low and high costs, this relationship evens out. These dependences make it possible to note that the region of high velocities is located inside the porous filling, which will take on erosional damage. For pilot testing, it is possible to provide a change in porosity both along the length of the valve and along its radius to ensure a linear pressure drop along the length of the porous backfill. Studies have also shown that the pressure distribution approaches linear with increasing water flow.

However, it is worth noting here that the positive factor found in the experiment is the absence of a pressure drop typical for most types of industrial valves. As already noted, the absence of pressure drops allows the valve to work without erosion damage to the body. To determine the operating lim- 
its for the hydraulic characteristic from the experimental data, the dependence of the pressure drop on the water flow rate in the porous layer was compiled, which was calculated as the difference between the pressure at the valve inlet and the pressure at the outlet from the porous layer. As can be seen from Fig. 4, this characteristic has a dependence close to linear, which is typical for flows through porous layers, for example, through soils.

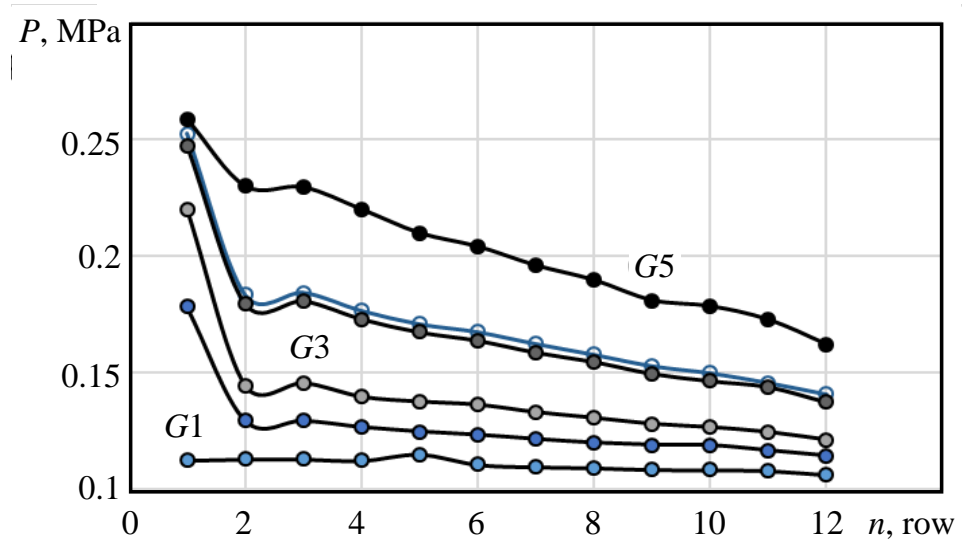

Fig. 3. Dependence of pressure on the height of the porous filling (a row of $n$ pressure sensors is located from the inlet to the outlet of the valve); G1-G5 is the water flow

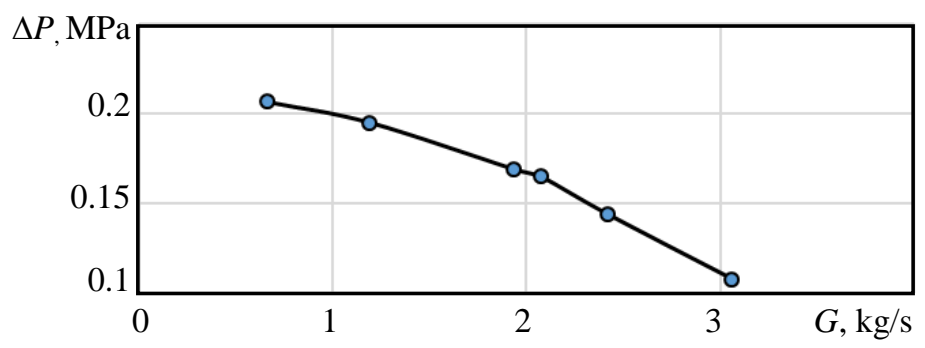

Fig. 4. Experimental hydraulic characteristics of a valve with porous filling

The boundary of the valve research area was limited by a water flow rate of $1.8 \mathrm{~kg} / \mathrm{s}$ and a working pressure at the inlet $P=0.32 \mathrm{MPa}$. To improve the design of this type of valve, it is necessary to conduct additional research on full-scale equipment.

\section{Conclusions}

1. The dependence of the pressure in the porous layer of the valve on the increase in water flow has been established. Nonlinear dependencies at average flow rates and linear at maximum and minimum flow rates are obtained. It is shown that, in such a valve, a section with a high fluid velocity will be in a porous filling.

2. Studies of the hydraulic characteristics of the proposed valve showed that this characteristic has a form close to linear, which is typical for flows in porous media.

\section{Література}

1. Имбрицкий М.И. Справочник по арматуре и трубопроводам химических цехов электростанций. Москва. : Энергоатомиздат, 1985. 168 с.

2. Иткина Д.М. Исполнительные устройства систем управления в химической и нефтехимической промышленности. Москва : Химия, 1984. 232 с.

3. Арзуманов Э.С. Гидравлические регулирующие органы систем автоматического управления. Москва : Машиностроение, 1985. 256 с.

4. Павлишин П.Я. Пошкодження енергетичної арматури і іï вхідний контроль. Праиі Одеського політехнічного університету. 2019. Вип. 3(59), С. 64-67. DOI: 10.15276/opu.3.59.2019.09. 
5. Причины и виды неисправностей запорной арматуры. URL: https:/tpa-asteko.ru/poleznyematerialy/106-prichiny-i-vidy-neispravnostej-zapornoj-armatury.

6. Казначеева И.В. Эрозионный износ энергетической арматуры. Вестник калужского универсиmema. 2013. № 3-4. С. 18-22.

7. Имбрицкий М.И. Надёжность арматуры энергетических блоков. Москва :Энергия, 1980. 95 с.

8. Соединение труб из разнородных металлов / Киселёв С.Н. и др. Москва : Машиностроение, 1981. $176 \mathrm{c.}$

9. Филлипов Г.А., Салтанов Г.А., Кукушкин А.Н. Гидродинамика и тепломассообмен в присутствии поверхностно-активных веществ. Москва : Энергоатомиздат, 1988. 184 с.

10. Сборник директивных материалов по эксплуатации энергосистем : Теплотехническая часть. Минэнерго СССР. Москва : Энергоатомиздат, 1981. 320 с.

\section{References}

1. Imbritsky, M.I. (1985). Handbook on fittings and pipelines of chemical shops of power plants. Moscow: Energoatomizdat.

2. Itkina, D.M. (1984). Actuators of control systems in the chemical and petrochemical industry. Moscow: Chemistry.

3. Arzumanov, E.S. (1985). Hydraulic regulating bodies of automatic control systems. Moscow: Mechanical engineering.

4. Pavlyshin, P.Y. (2019). Damage to power valves and their input control. Proceedings of Odessa Polytechnic University, 3(59), 64-67.

5. Causes and types of shut-off valve malfunctions. Retrieved from: https:/tpa-asteko.ru/poleznyematerialy/106-prichiny-i-vidy-neispravnostej-zapornoj-armatury.

6. Kaznacheeva, I.V. (2013). Erosive wear of power fittings. Bulletin of Kaluga University, 3-4, 18-22.

7. Imbritsky, M.I. (1980). Reliability of fittings of power units. Moscow: Energiya.

8. Kiselev S.N. et al. (1981). Connection of pipes from dissimilar metals. Moscow: Mechanical Engineering.

9. Fillipov, G.A., Saltanov, G.A., \& Kukushkin, A.N. (1988). Hydrodynamics and heat and mass transfer in the presence of surfactants. Moscow: Energoatomizdat.

10. Collection of guidelines for the operation of power systems (1981). Heat engineering part. USSR Ministry of Energy. Moscow: Energoatomizdat.

Корольов Олександр Вікторович; Koroliov Oleksandr, ORCID: https://orcid.org/0000-0002-4158-7966

Павлишин Павло Яремович; Pavlyshyn Pavlo, ORCID: https://orcid.org/0000-0002-3417-4346

Received August 11, 2020

Accepted October 21, 2020 